\title{
RUMEN FAUNA IN CALVES RAISED IN ISOLATION FROM THE DAMS
}

\author{
J. CRHA, A. HOLUB \\ Department of Physiology, University of Veterinary Science, 61242 Brno
}

Received November 21, 1978

\begin{abstract}
Crha J., A. Holub: Rumen Fauna in Calves Raised in Isolation from the Dams. Acta vet. Brno, 47, 1978: 127-135.

Six Slovak Spotted calves raised in isolation form their dams were examined for the presence of rumen protozoa from birth to 29 weeks of age. Entodinia were first observed 19 weeks after the animals had been fed roughage for 8 weeks. Eremoplastron spp. and Epidinium spp. occurred from the 25th week and Eudoplodinium spp. from the 27th week after birth. In three calves left with their dams for 20 days after birth entodinia were observed as early as 13 weeks after birth and epidinia and isotricha were present from the 18th week after birth.
\end{abstract}

Rumen microorganisms, protozoa, Entodiniomorpha, Holotricha.

There are conflicting reports as to the time at which protozoa first appear in the rumen of calves but it is, no doubt, rather late after birth. Although they may make their appearance in the first or second week after birth, provided that ruminal $\mathrm{pH}$ is higher than 6.0 they were generally demonstrated from the third week after birth (Lengemann and Allen 1959). According to other reports they do not appear until calves are 8 weeks old and then only in 15 per cent of animals (Latteur 1953), or even as late as 16 weeks after birth (Conrad et al. 1958).

These discrepancies are not surprising when one reflects that the time at which protozoa possibly with the exception of flagellates (Eadie 1962), appear in the rumen depends on contact of the calves with older, protozoa-harbouring animals (Strelkov et al. 1933; Pounden and Hibbs 1950; Bryant et al. 1958; Eadie 1962, Borhami et al. 1967).

It is therefore conceivable that the methods of rearing particularly under intensive husbandry conditions influence faunation of the calves to a considerable extent. Since early establishment of ciliates in the rumen is important to the development and growth of calves, all practices that advance or delay the onset of rumen faunation, thus affecting the progress of transformation of a suckling into a ruminant, are of great importance and may have far-reaching consequences.

\section{Animals}

\section{Material and Methods}

The experimental animals were Slovak Spotted calves. They were separated from the dams immediately after birth before being licked by the cows. They were transferred first to a calf house where they were given a shower-bath, were brushed and then individually penned in cages bedded with straw. They were fed a milk diet four times a day for the first four days and three times a day for the next 15 days. At 20 days of age they were shifted to granulated alfalfa meal. At one month of age they were changed to clover hay. After being penned in cages up to 11 weeks of age, the animals were transferred to another calf house, about $200 \mathrm{~m}$ distant from the previous one, where they were loose-housed. One week later they were transferred to a third calf house, about $200 \mathrm{~m}$ distant fromthe previous one, where they were housed about twenty to a pen and fed alfalfa and clover hay ad libitum, received barley-and-maize meal three times a day and were provided with water. Afterwards they were transferred to a fourth calf house, about $800 \mathrm{~m}$ distant from the previous one, where they were loose-housed and were fed on maize silage; once a week they received fresh green clover. The four calf houses were under the charge of different attendants. 
Six calves born during one week and raised as described above were included in the experiment. An additional three calves were left with their dams for 20 days after birth and then transferred to cages and raised in the same way as the calves separated from the dams immediately after birth.

\section{Collection of Samples}

Rumen liquor was collected by means of an oesophageal tube at 14-day intervals, invariably between 10 and $12 \mathrm{a}$. m., from the first week after birth. The liquor was strained through a sieve and diluted $1: 1(2 \mathrm{ml}+2 \mathrm{ml})$ with 10 per cent formol.

\section{Microscopical Examination}

The sediment of each sample was examined for the presence of ciliates. If they were present the sample was shaken and a portion of it was transferred to a Fuchs-Rosenthal chamber. The ciliates in each sample were counted four times; the results were averaged and were expressed per $1 \mathrm{ml}$. For species identification, the ciliates were stained with carmine dye (nuclei) and with modified Lugol's solution (skeleton plates) (Dogiel 1927, Kofoid and Mac Lennan 1930, 1932, 1933; Wertheim 1935; Lubinsky 1957; Noirot-Timothée 1960; Latteur 1966, 1968, 1970). Measurements were also made of

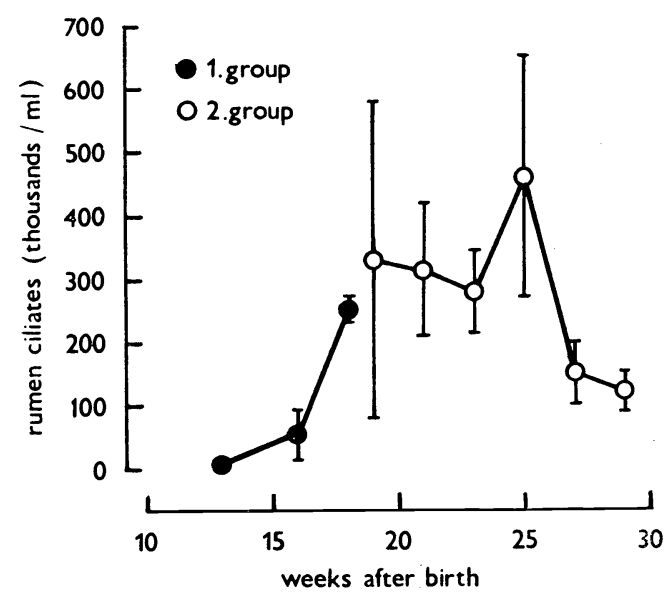
the dimensions of individual species.

\section{Results}

In isolated calves rumen ciliates were first observed 19 weeks after birth and were consistently found in all subsequent rumen liquor samples till the end of the experiment. The only genus represented up to 23 weeks after birth was Ento-

Fig. 1.

First appearance of ciliated protozoa in the rumen liquor of isolated calves (Group 2) and control calves kept with dams after birth (Group 1)

Table 1

Numbers of ciliated protozoa (thousands $/ \mathrm{ml}$ ) in the rumen liquor of isolated calves and control animals left with the dams after birth

\begin{tabular}{|c|c|c|c|c|c|c|}
\hline \multicolumn{3}{|l|}{ Isolated calves } & \multicolumn{4}{|l|}{$1000 \cdot \mathrm{ml}^{-1}$} \\
\hline Genus Week & 19. & 21. & 23. & 25. & 27. & 29. \\
\hline $\begin{array}{l}\text { Entodinium } \\
\text { Eremoplastron } \\
\text { Eudiplodinium } \\
\text { Polyplastron } \\
\text { Epidinium }\end{array}$ & $\begin{array}{c}334.2 \pm 253.25 \\
0 \\
0 \\
0 \\
0\end{array}$ & $\begin{array}{c}317.4 \pm 104.88 \\
0 \\
0 \\
0 \\
0\end{array}$ & $\begin{array}{c}281.0 \pm 63.70 \\
0 \\
0 \\
0 \\
0\end{array}$ & $\begin{array}{c}458.6 \pm 192.68 \\
0.2 \pm 0.16 \\
0 \\
0 \\
0.7 \pm 0.57\end{array}$ & $\begin{array}{c}134.5 \pm 45.72 \\
0.1 \pm 0.08 \\
7.8 \pm 7.69 \\
0.3 \pm 0.24 \\
6.5 \pm 2.83\end{array}$ & $\begin{array}{c}85.8 \pm 32.70 \\
26.8 \pm 10.74 \\
9.5 \pm 4.00 \\
0 \\
5.2 \pm 2.44\end{array}$ \\
\hline \multicolumn{3}{|c|}{ Calves left with the dams after birth } & \multicolumn{4}{|l|}{$1000 \cdot \mathrm{ml}^{-1}$} \\
\hline Genus Week & 13. & 16. & 18. & & & \\
\hline $\begin{array}{l}\text { Entodinium } \\
\text { Epidinium } \\
\text { Isotricha }\end{array}$ & $\begin{array}{c}4.8 \pm 4.30 \\
0 \\
0\end{array}$ & $\begin{array}{c}52.4 \pm 42.38 \\
0.2 \pm 0.16 \\
0\end{array}$ & $\begin{array}{c}252.8 \pm 166.72 \\
2.0 \pm 1.88 \\
0.2 \pm 0.16\end{array}$ & & & \\
\hline
\end{tabular}



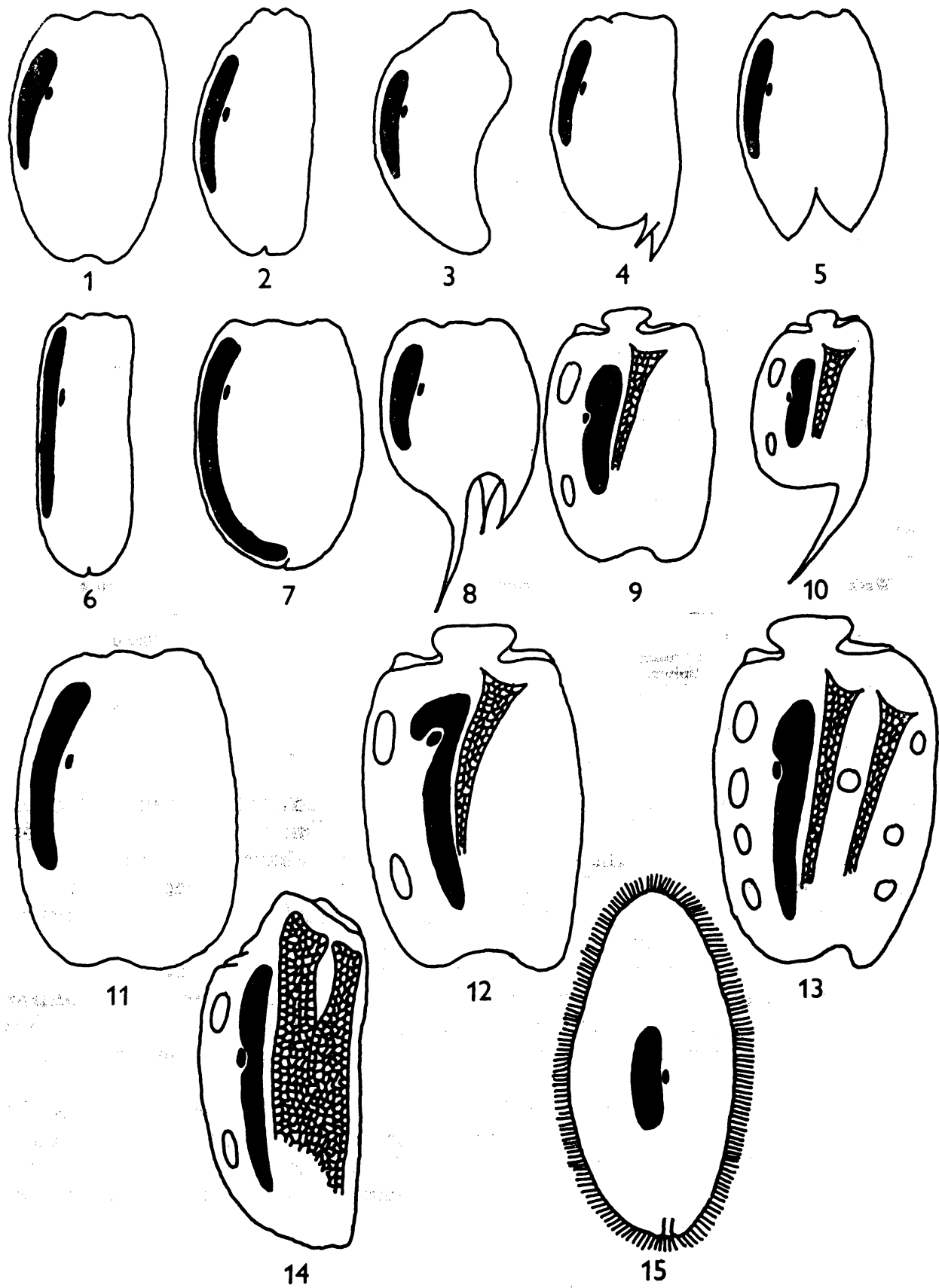

Fig. 2.

Schematic presentation of protozoal species in the rumen liquor of isolated calves 1 Entodinium simplex, 2 Entodinium elongatum, 3 Entodinium minimum, 4 Entodinium bifidum,

5 Entodinium dilobum, 6 Entodinium augustum, 7 Entodinium longinucleatum, 8 Entodinium caudatum,

9 Eremoplastron bovis, 10 Eremoplastron rostratum, 11 Entodinium bursa, 12 Eudiplodinium maggii, 13 Polyplastron multivesiculatum, 14 Epidinium ecaudatum, 15 Isotricha prostoma. 
Percentage proportions of protozoal genera in the rumen liquor of isolated calves and control animals left with the dams after birth

\begin{tabular}{|c|c|c|}
\hline Week & Genus & $\%$ incidence \\
\hline $\begin{array}{l}19 . \\
21 . \\
23 . \\
25 . \\
27 . \\
29 .\end{array}$ & $\begin{array}{l}\text { Entodinium } \\
\text { Entodinium } \\
\text { Entodinium } \\
\text { Entodinium } \\
\text { Eremoplastron } \\
\text { Epidinium } \\
\text { Entodinium } \\
\text { Eudiplodinium } \\
\text { Polyplastron } \\
\text { Eremoplastron } \\
\text { Epidinium } \\
\text { Entodinium } \\
\text { Eermoplastron } \\
\text { Eudiplodinium } \\
\text { Epidinium }\end{array}$ & $\begin{array}{r}100.00 \\
100.00 \\
100.00 \\
99.80 \\
0.04 \\
0.16 \\
90.67 \\
5.28 \\
0.17 \\
0.06 \\
3.82 \\
67.34 \\
21.07 \\
7.53 \\
4.06\end{array}$ \\
\hline \multicolumn{3}{|c|}{ Calves left with the dams after birth } \\
\hline Week & Genus & $\%$ incidence \\
\hline $\begin{array}{l}13 . \\
16 . \\
18 .\end{array}$ & $\begin{array}{l}\text { Entodinium } \\
\text { Entodinium } \\
\text { Epidinium } \\
\text { Entodinium } \\
\text { Epidinium } \\
\text { Isotricha }\end{array}$ & $\begin{array}{r}100.00 \\
99.68 \\
0.32 \\
99.08 \\
0.85 \\
0.07\end{array}$ \\
\hline
\end{tabular}

dinium. Samples collected from the 25th week of age onwards contained in addition Eremoplastron spp., Epidinium spp. and Eudiplodinium spp. In other words, ciliates first appeared after the calves were fed dry roughage for 8 weeks and the genera represented increased in number only after another 5 weeks in association with the shift to another diet (Fig 1, Tables 1 and 2). The first species to appear was Entodinium simplex followed by Entodinium bursa, Entodinium augustatum, Entodinium longinucleatum, Eremoplastron bovis, Epidinium ecaudatum, Entodinium bifidum, Eudiplodinium maggii, Entodiniium caudatum, Eremoplastron rostratum and Entodinium dilobum (Table 3). Large specimens of Entodinium bursa and Entodonium longinucleatum were to contain ciliates of the species Entodinium simplex.

In calves left with their dams after birth ciliates were first observed at 13 weeks of age, i. e. as early as the second week after the shift to roughage (Fig. 1, Tables 1 and 2). The first species to appear were Entodinium simplex and Entodinium bursa followed by Epidinium ecaudatum, Entodinium caudatum, Entodinium minimum and Isotricha prostoma.

\section{Discussion}

As might be expected, rumen ciliates appeared earlier in calves left with their dams than in calves strictly isolated from the dams immediately after birth. Oxford (1955) reported sequential establishment of entodinia before diplodinia before holotrichs. Bryant et al. (1958) found, similarly to our results, no proto- 
Table 3

Percentage proportions of protozoal species in the rumen liquor of isolated calves and control animals left with the dams after birth

\begin{tabular}{|c|c|c|}
\hline \multicolumn{3}{|c|}{ Isolated calves } \\
\hline Week & Species & $\%$ incidence \\
\hline $\begin{array}{l}19 . \\
21 . \\
23 . \\
25 . \\
27 .\end{array}$ & $\begin{array}{l}\text { Entodinium simplex } \\
\text { Entodinium simplex } \\
\text { Entodinium bursa } \\
\text { Entodinium augustatum } \\
\text { Entodinium simplex } \\
\text { Entodinium bursa } \\
\text { Entodinium simplex } \\
\text { Entodinium bursa } \\
\text { Entodinium longinucleatum } \\
\text { Eremoplastron bovis } \\
\text { Epidinium ecaudatum } \\
\text { Entodinium simplex } \\
\text { Entodinium bursa } \\
\text { Entodinium longinucleatum } \\
\text { Entodinium bifidum } \\
\text { Entodinium elongatum } \\
\text { Entodinium augustatum } \\
\text { Entodinium caudatum } \\
\text { Eremoplastron bovis } \\
\text { Eudiplodinium maggii } \\
\text { Epidinium ecaudatum } \\
\text { Polyplastron multivesiculatum } \\
\text { Entodinium simplex } \\
\text { Entodinium bursa } \\
\text { Entodinium longinucleatum } \\
\text { Entodinium dilobum } \\
\text { Entodinium minimum } \\
\text { Eremoplastron bovis } \\
\text { Eremoplastron rostratum } \\
\text { Eudiplodinium maggii } \\
\text { Epidinium ecaudatum }\end{array}$ & $\begin{array}{r}83.3 \\
100.0 \\
83.3 \\
33.3 \\
100.0 \\
66.6 \\
100.0 \\
100.0 \\
100.0 \\
16.6 \\
33.3 \\
100.0 \\
100.0 \\
100.0 \\
16.6 \\
16.6 \\
16.6 \\
16.6 \\
16.6 \\
100.0 \\
100.0 \\
16.6 \\
83.3 \\
33.3 \\
100.0 \\
66.6 \\
16.6 \\
83.3 \\
83.3 \\
100.0 \\
100.0\end{array}$ \\
\hline \multicolumn{3}{|c|}{ Calves left with the dams after birth } \\
\hline Week & Species & $\%$ incidence \\
\hline $\begin{array}{c}13 . \\
16 . \\
18 .\end{array}$ & $\begin{array}{l}\text { Entodinium simplex } \\
\text { Entodinium bursa } \\
\text { Entodinium simplex } \\
\text { Entodinium bursa } \\
\text { Epidinium ecaudatum } \\
\text { Entodinium simplex } \\
\text { Entodinium bursa } \\
\text { Entodinium caudatum } \\
\text { Entodinium minimum } \\
\text { Epidinium ecaudatum } \\
\text { Isotricha prostoma }\end{array}$ & $\begin{array}{r}33.3 \\
33.3 \\
66.6 \\
33.3 \\
33.3 \\
100.0 \\
66.6 \\
66.6 \\
33.3 \\
66.6 \\
33.3\end{array}$ \\
\hline
\end{tabular}

Table 4

Body lengths of protozoal species found in the rumen liquor of isolated calves and control animals left with the dams after birth

\begin{tabular}{|l|c|c|}
\hline \multicolumn{1}{|c|}{ Species } & Isolated calves & $\begin{array}{c}\text { Calves left with } \\
\text { the dams }\end{array}$ \\
\hline Entodinium simplex & $\mu \mathrm{m}$ & $\mu \mathrm{m}$ \\
\hline Entodinium bursa & $21-56$ & $35-63$ \\
Entodinium augustatum & $56-161$ & $56-70$ \\
Entodinium longinucleatum & $56-84$ & - \\
Entodinium bifidum & $42-105$ & - \\
Entodinium elongatum & 56 & $35-56$ \\
Entodinium caudatum & 80 & - \\
Entodinium minimum & 63 & - \\
Eremoplastron bovis & 42 & - \\
Eremoplastron rostratum & $79-77$ & - \\
Eudiplodinium maggii & $49-84$ & $119-182$ \\
Polyplastron multivesiculatum & $91-189$ & $245-258$ \\
Epidinium ecaudatum & 126 & $98-196$ \\
Isotricha prostoma & - & \\
\hline
\end{tabular}


zoa in three isolated calves during 13 weeks after birth; entodinia were first observed in these animals at 17 weeks of age after the calves were placed in contact with adult cattle and the sequence of establishment of entodinia, diplodinia and holotrichs was the same as reported by Oxford (1955). Naga et al. (1969) reported that Entodinium followed by Eudiplodinium were the first two genera to appear in the rumen of buffalo calves where ciliated protozoa were seen earlier than in cow calves in which isotrichs and entodinia occurred almost simultaneously.

Entodinia are therefore the first ciliates to appear in the rumen of ruminants. They are, with few exceptions, small in size and morphologically primitive and ingest starch grains and bacteria that are present in ruminants at this time. In our isolated calves as well as in the controls left with the dams the appearance of primitive entodinia was followed by morphologically more complicated ciliates such as epidinia which were not observed in cow and water buffalo calves in Egypt (Naga et al. 1969).

Rumen ciliates that are larger in size and have thicker skeletal plates (eudiplodinia, epidinia, ostracodinia) feed, for the most part, on grass scraps. However, diplodinia and Entodinium bursa (syn. Entodinium vorax) (Dogiel 1927), the largest species of primitive entodinia, are predacious. In our study we found predacious Entodinium bursa specimens containing specimens of Entodinium simplex. Moreover, we found large specimens of Entodinium longinucleatum with swallowed Entodinium simplex specimens. Also in the higher members of the family predatory habits were found only in species where large specimens occur (Lubinsky 1957).

A number of investigators have studied the presence of ciliates in young animals in relation to growth rate and health status. Belenkij (1953) reported that calves with gastric or intestinal disease had no ciliates in the rumen. Artifical faunation protected calves from coliparatyphoid and colibacillosis. Similarly, Williams and Dinuss on (1972) reported that two of three isolated calves developed scours, which is in keeping with our observations. Borhami et al. (1967) found a more rapid growth rate in inoculated than in uninoculated calves. Bryant and Small (1960) on the other hand, reported that the lack of a normal microbiological population in calves did not have any drastic effect on the animals' growth or health up to 17 weeks of age. According to Minakov (1967) rumen ciliates appear earlier in calves inoculated with rumen contents from adult cattle than in uninoculated calves. A milk diet did not promote the establishment of ciliates, but ciliates inoculated into milk-fed calves did not die. Williams and Dinusson (1972) described the case of an isolated female calf that was free of protozoa till she was artifically inseminated. The establishment of ciliated protozoa in the rumen of isolated calves can be hastened by artifical faunation, i. e. by inoculation with rumen contents from healthy adult animals. Faunation stimulates digestion in the ontogenesis of the calf. The processes of digestive function in young animals are associated with the formation of reflex response to food during the differentiation of the central nervous system (C. N. S.). The sooner the relation between digestive receptors and the C. N. S. is established, the better the process of digestion and, in consequence, the more rapid growth rate of the young (Belenkij 1953).

Natural transfaunation has been explained since the observations of Strelkov (1933) as a result of direct contact of young ruminants with adult ones through licking or the cud. The question, however, arises why ciliates do not appear in the 
rumen of calves immediately after birth and why only entodinia become established at first although one might expect that other protozoal species occurring in large numbers in adult cattle (Dogiel 1927; Wertheim 1934; Minakov 1967; Crha 1969; Vasily and Mitchel 1974; a. o.) would be transferred through the cud or licking at the same time. Rumen ciliates are anaerobes and are very sensitive to oxygen. In vitro, they survive only in a culture medium containing $0.7 \mathrm{mg}$ oxygen per $\mathrm{ml}$ (Gaumont and Grain 1967). The least air sensitive ciliates are entodinia and isotrichs (Sedloev 1973). On the other hand, rumen ciliates endure extremely well thermal shocks which they survive for several hours and continue to develop after being reexposed to their optimum growth temperature, i. e. $38^{\circ} \mathrm{C}$ (Florentin 1964, 1965). The replication of ciliates has been related among other things, to the intake of roughage. Bazadov and Prokudin (1959) reported that the appearance of rumen ciliates does not invariably coincide with the start of roughage feeding, but is often delayed, which is in keeping with our observations. Large quantities of rumen ciliates appear in calves after the animals are placed on fresh green forage; this was also the case in our experiments. There is also in vitro evidence to indicate that entodinia survive in rumen fluid much longer if fresh clover leaves are added (Kandacu and Takachasi 1956). Hungate (1966) found entodinia and diplodinia on sheep pasture plants, but neither cysts nor pseudocysts of these ciliates were detected as was demonstrated more recently by Nouzar ède (1965).

\section{Bachorová fauna u telat izolovaných od matek}

U šesti telat slovenského strakatého skotu, držených isolovaně od matek, byla od narození do 29. týdne života sledována přítomnost bachorových nálevníků. První z nich, a to rodu Entodinium se objevili u telat 19 týdnů starých, po osmitýdenním konsumu hrubé píce. Další, a to zástupci rodu Eremoplastron a Epidinium, byli zjištováni od 25. týdne a rodu Eudiplodinium od 27. týdne života telat. U tř́i telat, která byla v trvalém kontaktu s matkami, se nálevníci rodu Entodinium objevili v bachoru již ve 13. a rodu Epidinium a Isotricha v 18. týdnu života.

\section{Фауна первого желудка изолированных от коров-кормилиц телят}

У шести телят словацкого пестрого крупного рогатого скота, содержимых отдельно от коров-кормилиц, наблюдалось со дня рождения до 29 недели жизни присутствие инфузориев первого желудка. Первые из них, а именно рода Entodinium появились у телят в возрасте 19 недель после восьминедельного потребления грубого корма. Следующие, а именно представители родов Eremoplastron и Epidinium были установлены с 25 недели и рода Eudiplodinium - с 27 недели жизни телят. В случае трех телят, находящихся в постоянном контакте с коровами-кормилицами инфузории рода Entodinium появились в рубце уже в течение 13 недели и родов Epidinium и Isotricha - в течение 18 недели жизни.

\section{References}

BAZADOVA, N. U. - PROKUDIN, A. V.: K voprosu o mikrofauně predžaludkov u jagňat v ontogeneze. Tr. In-ta fysiol. AN Kaz. SSR, 2, 1959: 3-7.

BELENKKIJ, N. G.: Infuzorizacija těljat. Veterinarija, 30, 1953: 25-35. 
BORHAMI, B. E. A. - EL SHAZLY, K. - ABOU AKKADA, A. R. - AHMED, I. A.: Effect of Early Establishment of Ciliate Protozoa in the Rumen on Microbial Activity and Growth of Early Weaned Buffalo Calves. J. Dairy Sci., 50, 1967: 1954-1960.

BRYANT, M. P. - SMALL, N.: Observation on the ruminal microorganisms of isolated and inoculated calves. J. Dairy Sci., 43, 1960: 654-667.

BRYANT, M. P. - SMALL, N. - BOUMA, C. - ROBINSON, I.: Studies on the composition of the ruminal flora and fauna of young calves. J. Dairy Sci., 41, 1958: 1747-1767.

CONRAD, H. R. - HIBBS, J. W. - FRANK, N.: High Roughage System for Raising Calves Base on Early Development of Rumen Function. J. Dairy Sci., 41, 1958: 1248-1261.

CRHA, J.: Infusoria of the rumen of fattened cows. Acta vet. Brno, 38, 1969: 491 - 495.

DOGIEL, V. A.: Monographie der Familie Ophryoscolecidae. Arch. Protistenk., 59, 1927: 1-288.

EADIE, J. M.: The development of rumen microbial populations in lambs and calves under various conditions of management. J. Gen. Microbiol. 29, 1962: 563-578.

EADIE, J. M.: Inter-relationships between certain rumen ciliate protozoa. J. Gen. Microbiol. 29, 1962: 579-588.

FLORENTIN, A.: Action de la température et des chocs thermiques sur les cultures „in vitro“ des Ophryoscolecidae de la panse des ruminants. Ann. Univ. Assoc. reg. étude et rech. scient., 2, 1963-1964: 87-90.

FLORENTIN, A.: Action de quelques facteurs physiques sur la culture de cilliès oligotriches commensaux de la panse des ruminants. Arch. zool. exptl. etgén., 105, 1965: 193-199.

GAUMONT, R. - GRAIN, J.: L'anaérobiose et les mitochondries chez les protozoires du tube digestif. Ann. Univ. Assoc. rég. étude et rech. scient., 5, 1967: 174-176.

HUNGATE, R. E.: The rumen and its microbes. Academic Press New York, 1966.

KANDATSU, M. - TAKAHASHI, N.: Studies on the reticulo-rumen. 4. On the artificial culture of some Entodinia. J. Agric. Chem. Soc. Japan, 30, 1956: 96-99.

KOFOID, C. A. - MAC LENNAN, R. F.: Ciliates from Bos indicus L. I. The genus Entodinium Stein. Univ. Calif. Publ. Zool., 33, 1930: 471-544.

KOFOID, C. A. - MAC LENNAN, R. F.: Ciliates from Bos indicus L. II. A revision by Diplodinium Schuberg. Univ. Calif. Publ. Zool., 37, 1932: 53-152.

KOFOID, C. A. - MAC LENNAN, R. F.: Ciliates from Bos indicus L. III. Epidinium Crawley, Epiplastron gen. nov. and Ophryoscolex Stein. Univ., Calif. Publ. Zool., 39, 1933: 1-34.

LATTEUR, 1953 (cit.: JANCAR̂́K, A. - PROKŚOVÁ, M. - REICHL, J.: Biologie výživy sajících mládat, Praha, CSAZV, 1957).

LATTEUR, B.: Contribution à la systémàtique de la famille des Ophryoscolecidae Stein. Ann. Soc. Roy. Belg., 96, 1966: 117-144.

LATTEUR, B.: Revision systémátique de la famille des Ophryoscolecidae Stein 1898, sous-famille des Entodininae Lubinsky 1957, genre Entodinium Stein 1858. Ann. Soc. Roy. Zool., 98, 1968: $1-41$.

LATTEUR, B.: Révision systémàtique de la famille des Ophryoscolecidae Stein 1858. Sous-famille des Diploidiniinae Lubinsky 1957. Genre Diplodinium (Schuberg 1888) sensu novo. Ann. Soc. Roy. Zool., 100, 1970: 275-312.

LENGEMANN, F. W. - ALLEN, N. N.: Development of rumen function in the dairy calf. II. Effect of diet upon characteristics of the rumen flora and fauna of young calves. J. Dairy Sci., 42, 1959: 1171-1181.

LUBINSKY, G.: Studies on the evolution of the Ophryoscolecidae (Ciliata: Oligotricha). I. A new species of Entodinium with caudatum loboso-spinosum, and dubardi forms, and some evolutionary trends in the genus Entodinium. Canad. J. Zool., 35, 1957: 111-134.

LUBINSKY, G.: Studies on the evolution of the Ophryoscolecidae (Ciliata: Oligotricha) II. On the origin of the higher Ophryoscolecidae. Canad. J. Zool., 35, 1957: 135-140.

LUBINSKY, G.: Studien on the evolution of the Ophryoscolecidae (Ciliata: Oligotricha) III. Phylogeny of the Ophryoscolecidae based on the their comparative morphology. Canad. J. Zool. 35, 1957: 141-159.

LUBINSKY, G.: Note on the phylogenetics significance of predatory habits in the Ophryoscolecidae (Ciliata: Oligotricha). Canad. J. Zool., 35, 1957: 579-580.

MINAKOV, K. L.: K voprosu o značeniji infusorii rubca $v$ piščevarenii žvačnych. Sb. naučn. tr. Bologodsk. gos. s-ch. opytn. st., 5, 1967: 354-372.

NAGA, M. A. - ABOU AKKADA, A. R., EL SHAZLY, K.: Establishment of Rumen Ciliate Protozoa in Cow and Water Buffalo (Bos bubalus L.) Calves Under Late and Early Weaning Systems. J. Dairy Sci., 52, 1969: 110-112.

NOIROT-TIMOTHÉE, C.: Étude d'une famille de ciliés: Les „Ophryoscolecidae“. Structures et ultrastructures. Annales des Sc. Nat., Zool., 12, 1960: 527-718.

NOUZARÉDE, M.: L'infestation infusorienne des ruminants. Arch. zool. exptl. et gen., 105, 1965: 155-167. 
OXFORD, A. E.: The rumen ciliate protozoa: their chemicalcomposition, metabolism, requirements for maintenance and culture, and physiological significance for the host. Exptl. Parasitol., 4, 1955: 569-605.

POUNDEN, W. D. - HIBBS, J. W.: The development of calves raised without protoazoa and certain other characteristic microorganisms. J. Dairy Sci., 33, 1950: 639-644.

SEDLOEV, N. G.: Proučvane na njakoj svojstva na infusoriite a vrzkata jim s procesite na chrano osmilaneto $v$ trbucha na ovcata. Disertace, Sofia, 1973.

STRELKOV, A. A. - POLJANSKI, G. - ISAKOVA-KEO, M.: O putjach zaraženija žvačnych infusorijami naseljajuščimi rubec i setku, Tr. Lening. občs. jestěvstvoisp. 42, 1933.

VASILY, D. B. - MITCHELL, J. B.: The identification of rumen ciliates from eastern Bos taurus. Trans. Amer. Miscrosc. Soc., 93, 1973: 248-253.

WERTHEIM, P.: Statističko-faunistička istraživanja infusorija iz želuca Bos taurus L. Vet. Arhiv 4, 1934: $394-466$.

WERTHEIM, P.: Revision der Familie Ophryoscolecidae. Veterinarski Arhiv, 5, 1935: 388-536.

WILIAMS, P. P. - DINUSSON, W. E.: Composition of the ruminal flora and establishment of ruminal ciliated protozoal species in isolated calves. J. Anim. Sci., 34, 1972: 469-474. 